\title{
Perks of Working Entirely with Keyboard
}

\author{
Dr. Madhur Jain ${ }^{1}$, Rishabh Chauhan², Ayushi Bansal ${ }^{2}$ \\ ${ }^{1}$ Assistant Professor, Department of Information Technology, Bhagwan Parshuram Institute of Technology, \\ Delhi, India \\ 2Information Technology, Bhagwan Parshuram Institute of technology, Delhi, India
}

Article Info
Volume 7, Issue 6
Page Number: 47-56
Publication Issue :
November-December-2021
Article History
Accepted : 05 Nov 2021
Published : 14 Nov 2021

ABSTRACT

Working in today's corporate world requires users to switch between keyboard and mouse constantly. According to a survey conducted, an average user switches between keyboard and mouse 90 times in an hour. These frequent switches cause several discomforts to the user and the user's efficiency takes a major fall. Use of touchpad in place of mouse is one another major setback. It has been noticed that a user switching from mouse/touchpad to keyboard and vice versa consumes time in completing a task as compared to a user depending entirely on keyboard.

Keywords: Mouse, Keyboard, Carpal Tunnel Syndrome, Efficiency, Keyboard Shortcuts

\section{INTRODUCTION}

Every corporate environment requires users to spend hours every day engaging in computer activities which requires them to have great efficiency. These activities depend heavily on the speed at which users perform tasks. There are two ways to execute a set of operations. It can be either using a keyboard and a mouse or just a keyboard. These both methods cause a huge variation in time efficiency.

\section{A. Effects of using mouse}

Early researches on experienced users have shown that working entirely using the keyboard is a more efficient method for performing computerized tasks as compared to a mouse. The efficiency that the practiced users obtained by using the keyboard shortcuts instead of point and clicking via mouse is extraordinary, how a user can switch to multiple tasks in a blink of an eye using a single keystroke drives the productivity of the user to the next level. Apart from increasing efficiency, the use of a keyboard also aids in reducing the ill-effects caused by continuous use of a computer using a mouse. The excessive use of the mouse causes several wrist and hand discomforts which can also lead to CTS or Carpal Tunnel Syndrome.

\section{B. Carpal Tunnel Syndrome}

Carpal tunnel syndrome is a common condition that causes pain and numbness in the hands and arms. The condition

occurs when one of the major nerves of the hand the median nerve - is compressed as it travels 
through the wrist. This type of syndrome generally gets developed in the people who use the mouse excessively. The results have proved that entrants, who spend more time using the keyboard as compared to the mouse, had less chances of developing CTS. In most patients, carpal tunnel syndrome gets worse with time, so early diagnosis and proper treatment are necessary. At the start, symptoms can often be relieved by simple measures like wearing a wrist splint or avoiding certain activities. If pressure on the nerve continues, however, it can lead to worsening symptoms and even nerve damage. To prevent complete damage, surgery to take pressure off the median nerve is recommended for some patients.

Thus, it is our hypothesis that pointing tasks performed directly on the keyboard may result in less discomfort, but possibly at the cost of worse performance for pointing tasks.

\section{Wrist injuries}

There are two reasons why using a mouse regularly can be dangerous.

First, using a mouse requires the person to make small, concise movements with their wrist, fingers, and thumb. By positioning, travelling, and clicking the mouse buttons again and again, the small muscles can become tired and overworked. This overuse can cause:

- Pain on the top of the hand

- Pain around the wrist

- Pain along the forearm and elbow.

- Formulation of painful nodules, and later on, ganglion cysts, around the joints and along the tendons

- Numbness in the thumb and the index finger

- Burning, stiffness, restricted range of motion
The secondary reason using a computer mouse can be hazardous is that the placement of the mouse can make it difficult to reach. Almost every computer workstation has limited space; since the keyboard is already directly in front of the person using the computer, most of the time the mouse is placed around the upper right hand corner of the keyboard and towards the back of the desk.

Maintaining this position for the day can cause soreness and fatigue by putting an extra load in the muscles in the upper back and shoulder. Continuous use of the mouse, therefore, can cause aches and pains in the shoulder and neck. Lower back pain, which is not directly caused by the mouse, can also be a problem if the computer user has bad posture and leans forward while sitting.

\section{RESULTS}

\section{A. Experimental Trials}

To compute the effects of the condition and compare efficiency, trials were conducted for a number of participants. It was observed that a participant working entirely using a keyboard would complete in less time and with greater ease as compared to using both mouse \& keyboard simultaneously.

It was noticed that using only a keyboard would wind up the task in less time. A participant was given a task to complete using only a keyboard and using both keyboard and mouse. It was also seen that on an average,each participant took 30 minutes to complete the work using both mouse and keyboard whereas on the other hand, the task was completed in 25 minutes using just a keyboard.

An infographic by American Express Open Forum states that "an average person loses 2 seconds per minute of the work" just by switching back and forth between the mouse and keyboard. 
Dr. Madhur Jain et al Int. J. Sci. Res. Comput. Sci. Eng. Inf. Technol, November-December-2021, 7 (6) : 47-56

\section{A. Discussion}

The results show a clear advantage of using a keyboard over using both mouse and keyboard simultaneously. By assessing the completion time of the given tasks between both of the methods, it can be easily concluded that using only the keyboard is far superior in terms of efficiency and productivity. The reduction in completion time alone is sufficient for switching to the superior method, i.e. using only a keyboard.

\section{SOLUTIONS}

The best way to tackle this, for Windows users, is to reduce mouse usage by using more and more of keyboard shortcuts. On the other hand, Linux users can completely switch from mouse to keyboard.

Some of the important keyboard shortcuts for Windows users are mentioned below.

\begin{tabular}{|l|l|}
\hline \multicolumn{1}{|c|}{$\begin{array}{c}\text { Keyboard } \\
\text { shortcut }\end{array}$} & \multicolumn{1}{|c|}{ Action } \\
\hline Ctrl + A & Select all content. \\
\hline $\begin{array}{l}\text { Ctrl + C (or } \\
\text { Ctrl + Insert) }\end{array}$ & $\begin{array}{l}\text { Copy selected items to } \\
\text { clipboard. }\end{array}$ \\
\hline Ctrl + X & Cut selected items to clipboard. \\
\hline $\begin{array}{l}\text { Ctrl + V (or } \\
\text { Shift + } \\
\text { Insert) }\end{array}$ & Paste content from clipboard. \\
\hline Ctrl + Z & $\begin{array}{l}\text { Undo an action, including } \\
\text { undelete files (limited). }\end{array}$ \\
\hline Ctrl + Y & Redo an action. \\
\hline
\end{tabular}

\begin{tabular}{|c|c|}
\hline $\begin{array}{l}\text { Ctrl + Shift }+ \\
\mathrm{N}\end{array}$ & $\begin{array}{l}\text { Create a new folder on desktop } \\
\text { or File Explorer. }\end{array}$ \\
\hline Alt $+F 4$ & Close the active window. \\
\hline $\begin{array}{l}\text { Ctrl + D } \\
(\text { Del })\end{array}$ & $\begin{array}{l}\text { Delete selected item to the } \\
\text { Recycle Bin. }\end{array}$ \\
\hline $\begin{array}{l}\text { Shift + } \\
\text { Delete }\end{array}$ & $\begin{array}{l}\text { Delete the selected item } \\
\text { permanently, skipping Recycle } \\
\text { Bin. }\end{array}$ \\
\hline F2 & Rename selected item. \\
\hline ESC & Close current task. \\
\hline Alt + Tab & Switch between open apps. \\
\hline PrtScn & $\begin{array}{l}\text { Take a screenshot and store it in } \\
\text { the clipboard. }\end{array}$ \\
\hline $\begin{array}{l}\text { Windows } \\
\text { key + I }\end{array}$ & Open Settings app. \\
\hline $\begin{array}{l}\text { Windows } \\
\text { key }+\mathrm{E}\end{array}$ & Open File Explorer. \\
\hline $\begin{array}{l}\text { Windows } \\
\text { key }+\mathrm{A}\end{array}$ & Open Action center. \\
\hline $\begin{array}{l}\text { Windows } \\
\text { key + D }\end{array}$ & Display and hide the desktop. \\
\hline $\begin{array}{l}\text { Windows } \\
\text { key }+\mathrm{L}\end{array}$ & Lock device. \\
\hline $\begin{array}{l}\text { Windows } \\
\text { key }+\mathrm{V}\end{array}$ & Open the Clipboard bin. \\
\hline $\begin{array}{l}\text { Windows } \\
\text { key + Period } \\
\text { (.) or } \\
\text { semicolon (;) }\end{array}$ & Open emoji panel. \\
\hline
\end{tabular}


Dr. Madhur Jain et al Int. J. Sci. Res. Comput. Sci. Eng. Inf. Technol, November-December-2021, 7 (6) : 47-56

\begin{tabular}{|l|l|}
\hline $\begin{array}{l}\text { Windows } \\
\text { key + PrtScn }\end{array}$ & $\begin{array}{l}\text { Capture the full screenshot in } \\
\text { the "Screenshots" folder. }\end{array}$ \\
\hline $\begin{array}{l}\text { Windows } \\
\text { key + Shift + } \\
\text { S }\end{array}$ & $\begin{array}{l}\text { Capture part of the screen with } \\
\text { Snip \& Sketch. }\end{array}$ \\
\hline $\begin{array}{l}\text { Windows } \\
\text { key + Left } \\
\text { arrow key }\end{array}$ & Snap app or window left. \\
\hline $\begin{array}{l}\text { Windows } \\
\text { key + Right } \\
\text { arrow key }\end{array}$ & Snap app or window right. \\
\hline
\end{tabular}

\begin{tabular}{|c|c|}
\hline $\begin{array}{l}\text { Alt }+ \\
\text { Underlined } \\
\text { letter }\end{array}$ & $\begin{array}{l}\text { Runs command for the } \\
\text { underlined letter in apps. }\end{array}$ \\
\hline Alt + Tab & $\begin{array}{l}\text { Switch between open apps while } \\
\text { pressing Tab multiple times. }\end{array}$ \\
\hline $\begin{array}{l}\text { Alt }+ \text { Left } \\
\text { arrow key }\end{array}$ & Go back. \\
\hline $\begin{array}{l}\text { Alt }+ \text { Right } \\
\text { arrow key }\end{array}$ & Go forward. \\
\hline $\begin{array}{l}\text { Alt + Page } \\
\text { Up }\end{array}$ & Move up one screen. \\
\hline $\begin{array}{l}\text { Alt }+ \text { Page } \\
\text { Down }\end{array}$ & Move down one screen. \\
\hline Alt + Esc & Cycle through open windows. \\
\hline $\begin{array}{l}\text { Alt }+ \\
\text { Spacebar }\end{array}$ & $\begin{array}{l}\text { Open context menu for the active } \\
\text { window. }\end{array}$ \\
\hline Alt + F8 & $\begin{array}{l}\text { Reveals typed password in Sign-in } \\
\text { screen. }\end{array}$ \\
\hline $\begin{array}{l}\text { Shift }+ \text { Click } \\
\text { app button }\end{array}$ & $\begin{array}{l}\text { Open another instance of an app } \\
\text { from the Taskbar. }\end{array}$ \\
\hline $\begin{array}{l}\text { Ctrl }+ \text { Shift }+ \\
\text { Click app } \\
\text { button }\end{array}$ & $\begin{array}{l}\text { Run app as administrator from } \\
\text { the Taskbar. }\end{array}$ \\
\hline $\begin{array}{l}\text { Shift }+ \\
\text { Right-click } \\
\text { app button }\end{array}$ & $\begin{array}{l}\text { Show window menu for the app } \\
\text { from the Taskbar. }\end{array}$ \\
\hline $\begin{array}{l}\text { Ctrl + Click a } \\
\text { grouped app } \\
\text { button }\end{array}$ & $\begin{array}{l}\text { Cycle through windows in the } \\
\text { group from the Taskbar. }\end{array}$ \\
\hline $\begin{array}{l}\text { Shift }+ \\
\text { Right-click } \\
\text { grouped app } \\
\text { button }\end{array}$ & $\begin{array}{l}\text { Show window menu for the } \\
\text { group from the Taskbar. }\end{array}$ \\
\hline
\end{tabular}

\begin{tabular}{|l|l|}
\hline \multicolumn{1}{|c|}{$\begin{array}{c}\text { Keyboard } \\
\text { shortcut }\end{array}$} & \multicolumn{1}{|c|}{ Action } \\
\hline $\begin{array}{l}\text { Windows } \\
\text { key (or Ctrl } \\
+ \text { Esc) }\end{array}$ & Open Start menu. \\
\hline $\begin{array}{l}\text { Ctrl }+ \text { Arrow } \\
\text { keys }\end{array}$ & Change Start menu size. \\
\hline $\begin{array}{l}\text { Ctrl }+ \text { Shift }+ \\
\text { Esc }\end{array}$ & Open Task Manager. \\
\hline Ctrl + Shift & Switch keyboard layout. \\
\hline Alt + F4 & Close active window. (If no active \\
window is present, then a \\
shutdown box appears.)
\end{tabular}


Dr. Madhur Jain et al Int. J. Sci. Res. Comput. Sci. Eng. Inf. Technol, November-December-2021, 7 (6) : 47-56

\begin{tabular}{|c|c|c|c|}
\hline $\begin{array}{l}\text { Ctrl }+ \text { Left } \\
\text { arrow key }\end{array}$ & $\begin{array}{l}\text { Move the cursor to the beginning } \\
\text { of the previous word. }\end{array}$ & $\begin{array}{l}\text { Windows } \\
\text { key }+\mathrm{M}\end{array}$ & Minimize all windows. \\
\hline $\begin{array}{l}\text { Ctrl + Right } \\
\text { arrow key }\end{array}$ & $\begin{array}{l}\text { Move the cursor to the beginning } \\
\text { of the next word. }\end{array}$ & $\begin{array}{l}\text { Windows } \\
\text { key }+ \text { Shift }+ \\
\text { M }\end{array}$ & $\begin{array}{l}\text { Restore minimized windows on } \\
\text { the desktop. }\end{array}$ \\
\hline $\begin{array}{l}\text { Ctrl }+ \text { Up } \\
\text { arrow key }\end{array}$ & $\begin{array}{l}\text { Move the cursor to the beginning } \\
\text { of the previous paragraph }\end{array}$ & $\begin{array}{l}\text { Windows } \\
\text { key }+ \text { Home }\end{array}$ & $\begin{array}{l}\text { Minimize or maximize all but the } \\
\text { active desktop window. }\end{array}$ \\
\hline $\begin{array}{l}\text { Ctrl }+ \text { Down } \\
\text { arrow key }\end{array}$ & $\begin{array}{l}\text { Move the cursor to the beginning } \\
\text { of the next paragraph. }\end{array}$ & \multirow{2}{*}{$\begin{array}{l}\text { Windows } \\
\text { key + Shift + } \\
\text { Up arrow } \\
\text { key }\end{array}$} & \multirow[t]{2}{*}{$\begin{array}{l}\text { Stretch the desktop window to } \\
\text { the top and bottom of the screen. }\end{array}$} \\
\hline Ctrl + Shift + & Select block of text. & & \\
\hline $\begin{array}{l}\text { Ctrl + } \\
\text { Spacebar }\end{array}$ & Enable or disable Chinese IME. & \multirow{2}{*}{$\begin{array}{l}\text { Windows } \\
\text { key }+ \text { Shift }+ \\
\text { Down arrow } \\
\text { key }\end{array}$} & \multirow[t]{2}{*}{$\begin{array}{l}\text { Maximize or minimize active } \\
\text { desktop windows vertically while } \\
\text { maintaining width. }\end{array}$} \\
\hline Shift + F10 & Open context menu for selected & & \\
\hline & item. & \multirow{3}{*}{$\begin{array}{l}\text { Windows } \\
\text { key }+ \text { Shift }+ \\
\text { Left arrow } \\
\text { key }\end{array}$} & \multirow{3}{*}{$\begin{array}{l}\text { Move the active window to } \\
\text { monitor on the left. }\end{array}$} \\
\hline F10 & Enable app menu bar. & & \\
\hline Shift + & Select multiple items. & & \\
\hline Arrow keys & & \multirow{2}{*}{$\begin{array}{l}\text { Windows } \\
\text { key + Shift + } \\
\text { Right arrow } \\
\text { key }\end{array}$} & \multirow{2}{*}{$\begin{array}{l}\text { Move the active window to } \\
\text { monitor on the right. }\end{array}$} \\
\hline $\begin{array}{l}\text { Windows } \\
\text { key }+X\end{array}$ & Open Quick Link menu. & & \\
\hline $\begin{array}{l}\text { Windows } \\
\text { key }+ \\
\text { Number (0- } \\
\text { 9) }\end{array}$ & $\begin{array}{l}\text { Open app in number position } \\
\text { from the Taskbar. }\end{array}$ & $\begin{array}{l}\text { Windows } \\
\text { key }+ \text { Left } \\
\text { arrow key }\end{array}$ & Snap app or window left. \\
\hline $\begin{array}{l}\text { Windows } \\
\text { key }+\mathrm{T}\end{array}$ & $\begin{array}{l}\text { Cycle through apps in the } \\
\text { Taskbar. }\end{array}$ & $\begin{array}{l}\text { Windows } \\
\text { key + Right } \\
\text { arrow key }\end{array}$ & Snap app or window right. \\
\hline $\begin{array}{l}\text { Windows } \\
\text { key + Alt + } \\
\text { Number (0- } \\
\text { 9) }\end{array}$ & $\begin{array}{l}\text { Open Jump List of the app in } \\
\text { number position from the } \\
\text { Taskbar. }\end{array}$ & $\begin{array}{l}\text { Windows } \\
\text { key + S (or } \\
\text { Q) }\end{array}$ & Open Search. \\
\hline $\begin{array}{l}\text { Windows } \\
\text { key }+\mathrm{D}\end{array}$ & Display and hide the desktop. & $\begin{array}{l}\text { Windows } \\
\text { key }+ \text { Alt }+ \text { D }\end{array}$ & $\begin{array}{l}\text { Open date and time in the } \\
\text { Taskbar. }\end{array}$ \\
\hline
\end{tabular}


Dr. Madhur Jain et al Int. J. Sci. Res. Comput. Sci. Eng. Inf. Technol, November-December-2021, 7 (6) : 47-56

\begin{tabular}{|l|l|}
\hline $\begin{array}{l}\text { Windows } \\
\text { key }+\mathrm{Tab}\end{array}$ & Open Task View. \\
\hline $\begin{array}{l}\text { Windows } \\
\text { key }+ \text { Ctrl }+ \\
\mathrm{D}\end{array}$ & Create a new virtual desktop. \\
\hline $\begin{array}{l}\text { Windows } \\
\text { key }+ \text { Ctrl }+ \\
\text { F4 }\end{array}$ & Close active virtual desktop. \\
\hline $\begin{array}{l}\text { Windows } \\
\text { key }+ \text { Ctrl }+ \\
\text { Right arrow }\end{array}$ & $\begin{array}{l}\text { Switch to the virtual desktop on } \\
\text { the right. }\end{array}$ \\
\hline $\begin{array}{l}\text { Windows } \\
\text { key }+ \text { Ctrl }+ \\
\text { Left arrow }\end{array}$ & $\begin{array}{l}\text { Switch to the virtual desktop on } \\
\text { the left. }\end{array}$ \\
\hline $\begin{array}{l}\text { Windows } \\
\text { key }+ \text { P }\end{array}$ & Open Project settings. \\
\hline $\begin{array}{l}\text { Windows } \\
\text { key }+ \text { A }\end{array}$ & Open Action center. \\
\hline $\begin{array}{l}\text { Windows } \\
\text { key }+ \text { I }\end{array}$ & Open Settings app. \\
\hline $\begin{array}{l}\text { Backspace } \\
\text { peturn to Settings app home }\end{array}$ \\
\hline
\end{tabular}

\begin{tabular}{|c|c|}
\hline $\mathrm{Ctrl}+\mathrm{F}$ (or F3) & Start searching. \\
\hline $\begin{array}{l}\text { Ctrl }+ \text { Mouse } \\
\text { scroll wheel }\end{array}$ & Change view file and folder. \\
\hline Ctrl + Shift + E & $\begin{array}{l}\text { Expands all folders from the } \\
\text { tree in the navigation pane. }\end{array}$ \\
\hline Ctrl + Shift $+N$ & $\begin{array}{l}\text { Creates a new folder on desktop } \\
\text { or File Explorer. }\end{array}$ \\
\hline $\mathrm{Ctrl}+\mathrm{L}$ & Focus on the address bar. \\
\hline $\begin{array}{l}\text { Ctrl }+ \text { Shift }+ \\
\text { Number }(1-8)\end{array}$ & Changes folder view. \\
\hline Alt $+\mathrm{P}$ & Display preview panel. \\
\hline Alt + Enter & $\begin{array}{l}\text { Open Properties settings for the } \\
\text { selected item. }\end{array}$ \\
\hline $\begin{array}{l}\text { Alt }+ \text { Right } \\
\text { arrow key }\end{array}$ & View the next folder. \\
\hline $\begin{array}{l}\text { Alt }+ \text { Left } \\
\text { arrow key (or } \\
\text { Backspace) }\end{array}$ & View previous folder. \\
\hline Alt + Up arrow & $\begin{array}{l}\text { Move up a level in the folder } \\
\text { path. }\end{array}$ \\
\hline F11 & $\begin{array}{l}\text { Switch active window full- } \\
\text { screen mode. }\end{array}$ \\
\hline F5 & $\begin{array}{l}\text { Refresh the instance of File } \\
\text { Explorer. }\end{array}$ \\
\hline F2 & Rename selected item. \\
\hline F4 & Switch focus to address bar. \\
\hline F5 & $\begin{array}{l}\text { Refresh File Explorer's current } \\
\text { view. }\end{array}$ \\
\hline
\end{tabular}

\begin{tabular}{|l|l|}
\hline \multicolumn{1}{|c|}{$\begin{array}{c}\text { Keyboard } \\
\text { shortcut }\end{array}$} & \multicolumn{1}{c|}{ Action } \\
\hline $\begin{array}{l}\text { Windows key + } \\
\text { E }\end{array}$ & Open File Explorer. \\
\hline Alt + D & Select address bar. \\
\hline Ctrl + E (or F) & Select search box. \\
\hline Ctrl + N & Open a new window. \\
\hline Ctrl + W & Close the active window. \\
\hline
\end{tabular}


Dr. Madhur Jain et al Int. J. Sci. Res. Comput. Sci. Eng. Inf. Technol, November-December-2021, 7 (6) : 47-56

\begin{tabular}{|c|c|}
\hline F6 & $\begin{array}{l}\text { Cycle through elements on the } \\
\text { screen. }\end{array}$ \\
\hline Home & Scroll to the top of the window. \\
\hline End & $\begin{array}{l}\text { Scroll to the bottom of the } \\
\text { window. }\end{array}$ \\
\hline
\end{tabular}

Linux users can completely switch from mouse to keyboard using some of the following tools and softwares.

\section{A. Vim}

Vim is a free and open-source, text editor program for Unix. Vim is designed to be used both from a command-line interface and as well as a standalone application in a graphical user interface. There is no need to reach for the mouse again as everything is a mere keypress or combination away with almost 200 functions specified for text editing. Vim does support the mouse, but it's designed so we don't have to use it for greater efficiency.

A mouse is useless when you are using Vim. We are forced to do everything with the keyboard, and it makes us a stronger, more efficient developer. The more we take our hands off the keyboard and use the mouse, the less effective we are while working. Each mouse movement is effectively a mini-context switch that slowly destroys your overall efficiency. We should learn to use keyboard shortcuts. A benefit of Vim is that it's entirely keyboard shortcuts. We can't use the mouse.

\section{B. Window Manager}

Window Manager makes extensive use of keyboard shortcuts to control different aspects of your environment. These include opening the terminal and other programs, resizing and positioning windows,

changing layouts, and even exiting wm. When you start using a window manager, you need to memorize a few of those shortcuts to get around and, with time, you'll use more of them.

The main benefit is that you don't often need to switch contexts from the keyboard to the mouse. With practice, it means you'll improve the speed and efficiency of your workflow.

For example, to open a new terminal, press $<$ SUPER $>+<$ ENTER $>$. Since the windows are automatically positioned, you can start typing your commands right away. Combine that with a nice terminal-driven text editor (e.g., Vim) and a keyboard-focused browser for a fully keyboard-driven workflow.

In a window manager, you can define shortcuts for everything. Here are some examples:

- Open terminal

- Open browser

- Change layouts

- Resize windows

- Control music player

- Switch workspaces

\section{Command-Line Interface}

If the user knows the correct commands then the command-line interface can be much faster than any other type of interface. Some of the commands are listed below

man command - Show manual for command pwd - Prints the full name (the full path) of current/working directory

ls - List directory contents

ls -a - List all the content, including hidden files

ls -1 - List the content and its information 
Dr. Madhur Jain et al Int. J. Sci. Res. Comput. Sci. Eng. Inf. Technol, November-December-2021, 7 (6) : 47-56

mkdir foldername - Create a new directory foldername

cd foldername - Change the working directory to foldername

cd - Return to $\$ H O M E$ directory

cd .. - Go up a directory

cd - - Return to the previous directory

emacs, nano, vi - File editors

cp source destination - Copy source to destination

cp -r source destination - Copy a directory recursively from source to destination

mv source destination - Move (or rename) a file from source to destination

rm file1 - Remove file1

rm -r folder - Remove a directory and its contents recursively

cat file - Print contents of file on the screen

less file - View and paginate file

head file - Show first 10 lines of file

tail file-Show last 10 lines of file

\section{Command-Line Tools}

Command line tools are scripts and programs that are created with a unique purpose, generally to solve a problem that the creator of that particular tool had faced. There is mostly a command line alternative to a GUI tool and using the command line alternative can boost up productivity significantly. Some of the command-line tools are mentioned below.

\section{E. Ranger}

Ranger is a dynamic UI for complete system file management needs. It supports VI bindings for easier access across the whole of your file system. The interface focuses on a minimal design, emphasizing on the structure of each directory. Additionally, you can also customize Ranger with external plugins, or you can build your own.

Key Features:

- Supports the file management operations.

- File and the directory previews.

- Filetype detection and also automated execution.

\section{F. Qute Browser}

Qutebrowser is a keyboard-only web browser for Linux, Windows, and macOS operating systems with VI key bindings and a minimal interface. It is completely keyboard-driven and is inspired by similar applications such as Vimperator and dwb. It accesses DuckDuckGo as the default search engine. qutebrowser is included in the native repositories of Linux distributions including Fedora, Arch Linux, etc. Similar to Vim and vi, the browser has a command mode and an insert mode. In command mode key binds can be used to perform different functions, for ex: 'G' to go to the bottom of a page, and 'gg' to the top. Specific commands can be bound to keysequences by the user.

\section{G. Wikit}

Wikit is a free and open source CLI program for easily accessing Wikipedia resources of search queries; it is built using Nodejs. The verb Wikit means looking up for something on wikipedia.org, the popular open source encyclopedia on the Internet. 
Dr. Madhur Jain et al Int. J. Sci. Res. Comput. Sci. Eng. Inf. Technol, November-December-2021, 7 (6) : 47-56

\section{H. Googler}

Googler is a powerful and feature-rich CLI tool for accessing Google Search within the Linux terminal.

It provides a CLI to Google search and displays results informing of title, URL and other abstract information in pages, with page navigation similar to that on a graphical web browser.

\section{Custom shortcuts and Scripts}

Knowing the right keyboard shortcuts can make a big difference in how quickly you can get things doneand if the hotkeys you need aren't available, it's not difficult to create your own. Whether you need to launch a specific application regularly or have a folder you need quick access to, or want to enable a particular service, you can set up a keyboard combination to ease your work. Keyboard shortcuts are one of the fastest ways to increase your PC productivity. Being able to simply click a button or two and get the results you need reduces your dependence on your mouse, which increases the amount of time you have to do what's most important.

\section{CONCLUSION}

Based on the findings from this research, it can be concluded that depending entirely on the mouse can increase user efficiency and also greatly reduce the risk of wrist injuries and developing carpal tunnel syndrome. The usage of above mentioned tools and resources can prove beneficial to every type of user in boosting their productivity. An infographic by American Express Open Forum states that "an average person loses 2 seconds per minute of work" just by switching back and forth between the mouse and the keyboard. This finding can be used to prove the fact that depending entirely on the keyboard can save a lot of time.

\section{REFERENCES}

[1]. Jorgensen, A. H., Garde, A. H., Laursen, B., \& Jensen, B. R. (2002). Using mouse and keyboard under time pressure: preference, strategies, and learning. Behavioral and Brain Sciences, 21, 317-319.

[2]. Isam Atroshi, Christina Gummesson, Ewald Ornstein, Ragnar Johnsson, and Jonas Ranstam. 2007. Carpal tunnel syndrome and keyboard use at work: a population based study. Arthritis and rheumatism 56, 11: 3620-5. http://doi.org/10.1002/art.22956

[3]. Stuart K. Card, William K. English, and Betty J. Burr. 1978. Evaluation of Mouse, RateControlled Isometric Joystick, Step Keys, and Text Keys for Text Selection on a CRT. In Human-computer interaction, R. M. Baecker and W. A. S. Buxton (Eds.). Morgan Kaufmann Publishers Inc., San Francisco, CA, USA 21, 8: 386-392.

http://doi.org/10.1080/00140137808931762

[4]. Mircea Fagarasanu and Shrawan Kumar. 2003. Carpal tunnel syndrome due to keyboarding and mouse tasks: a review. International Journal of Industrial Ergonomics 31, 2: 119$136 . \quad$ http://doi.org/10.1016/S01698141(02)00180-4

[5]. Alan Hedge. 2003. Computer use and risk of carpal tunnel syndrome. JAMA : the journal of the American Medical Association 290, 18541855. http://doi.org/10.1001/jama.290.14.1854-a

[6]. Peter W. Johnson, Steven L. Lehman, and David M. Rempel. 1996. Measuring muscle fatigue during computer mouse use. Proceedings of 18th Annual International Conference of the IEEE Engineering in Medicine and Biology Society, 1454-1455. http://doi.org/10.1109/IEMBS.1996.647501

[7]. Pranav Mistry and Pattie Maes. 2011. Mouseless: A Computer Mouse as Small as Invisible. In CHI '11 Extended Abstracts on 
Dr. Madhur Jain et al Int. J. Sci. Res. Comput. Sci. Eng. Inf. Technol, November-December-2021, 7 (6) : 47-56

Human Factors in Computing Systems (CHI EA

'11). ACM, New York, NY, USA, 1099- 1104.

http://doi.org/10.1145/1979742.1979715

\section{Cite this article as :}

Dr. Madhur Jain, Rishabh Chauhan, Ayushi Bansal, "Perks of Working Entirely with Keyboard", International Journal of Scientific Research in Computer Science, Engineering and Information Technology (IJSRCSEIT), ISSN : 2456-3307, Volume 7 Issue 6, pp. 47-56, November-December 2021. Available at doi : https://doi.org/10.32628/CSEIT21764 Journal URL : https://ijsrcseit.com/CSEIT21764 